\title{
Soil contamination with silver nanoparticles reduces Bishop pine growth and ectomycorrhizal diversity on pine roots
}

\author{
M. J. Sweet $\mathbb{B} \cdot$ I. Singleton
}

Received: 18 October 2014/Accepted: 5 November 2015/Published online: 21 November 2015

(C) The Author(s) 2015. This article is published with open access at Springerlink.com

\begin{abstract}
Soil contamination by silver nanoparticles (AgNP) is of potential environmental concern but little work has been carried out on the effect of such contamination on ectomycorrhizal fungi (EMF). EMF are essential to forest ecosystem functions as they are known to enhance growth of trees by nutrient transfer. In this study, soil was experimentally contaminated with $\operatorname{AgNP}(0,350$ and $790 \mathrm{mg} \mathrm{Ag} / \mathrm{kg}$ ) and planted with Bishop pine seedlings. The effect of AgNP was subsequently measured, assessing variation in pine growth and ectomycorrhizal diversity associated with the root system. After only 1 month, the highest AgNP
\end{abstract}

Electronic supplementary material The online version of this article (doi:10.1007/s11051-015-3246-4) contains supplementary material, which is available to authorised users.

M. J. Sweet $(\square)$

Environmental Sustainability Research Centre, College of Life and Natural Sciences, University of Derby, Kedleston Road, Derby DE22 1GB, UK

e-mail: m.sweet@derby.ac.uk

I. Singleton

School of Biology, Newcastle University, Ridley

Building, Newcastle upon Tyne NE1 7RU, UK

I. Singleton

School of Life, Sport and Social Sciences, Edinburgh

Napier University, Sighthill campus Sighthill Court,

Edinburgh EH11 4BN, UK level had significantly reduced the root length of pine seedlings, which in turn had a small effect on above ground plant biomass. However, after 4 months growth, both AgNP levels utilised had significantly reduced both pine root and shoot biomass. For example, even the lower levels of AgNP (350 mg $\mathrm{Ag} / \mathrm{kg}$ ) soil, reduced fresh root biomass by approximately $57 \%$. The root systems of the plants grown in AgNP-contaminated soils lacked the lateral and fine root development seen in the control plants (no AgNP). Although, only five different genera of EMF were found on roots of the control plants, only one genus Laccaria was found on roots of plants grown in soil containing $350 \mathrm{mg} \mathrm{AgNP} / \mathrm{kg}$. At the higher levels of AgNP contamination, no EMF were observed. Furthermore, extractable silver was found in soils containing AgNP, indicating potential dissolution of silver ions $(\mathrm{Ag}+)$ from the solid $\mathrm{AgNP}$.

Keywords AgNP - Fungi $\cdot$ Pine $\cdot$ Nanoparticle . Environmental effects

\section{Introduction}

Nanoparticles are increasingly being used in a wide variety of commercial applications, and this widespread use means that they will inevitably become common environmental contaminants. This contamination can occur either, indirectly, by entering waste 
streams for example, or directly, in the case of agricultural applications (Zhang et al. 2012). Silver nanoparticles (AgNP) in particular are used extensively due to their antimicrobial properties (Marambio-Jones and Hoek 2010; Mathew and Kuriakose 2013), and AgNPs are currently utilised commercially in such instances as textiles, disinfectants, chopping boards, washing machines and even for organ transplantation (Sweet and Singleton 2011). Recent work has shown that AgNP-treated commercial clothing (e.g. socks and t-shirts) can release a significant amount of AgNP into the environment via the water from washing machines (up to $650 \mathrm{mg} / 500 \mathrm{~mL}$ water). This provides a pathway whereby AgNP can reach the external environment, via waste-water treatment plants and ultimately entry into sewage sludge/biosolids (Benn and Westerhoff 2008). Other authors have also highlighted the potential for nanoparticles to enter the environment from different consumer products (Benn et al. 2010; Farkas et al. 2011). Biosolids are often used in commercial forestry and can be used to enhance seedling establishment (Valdecantos and Cortina 2011). This direct use of contaminated biosolids means that young trees (such as young pine) and their associated microbes could be directly exposed to nanoparticles. Trees, such as pine, benefit from fungal associations with their roots (Sousa et al. 2012), and these ectomycorrhizal fungi are proposed to aid tree growth by various potential mechanisms including improved nutrient uptake and stress tolerance (Finlay 2008; Gordon and Gehring 2011). Soil contamination with AgNP has been shown to affect specific microbes; however, much of the work has been focused on effects on bacteria, such as species from the genus Bradyrhizobium (Kumar et al. 2011). As far as the authors are aware, no work has been carried out on the effect of AgNP contamination on beneficial ectomycorrhizal fungal colonisation of tree roots despite the known antifungal effects of AgNP (George et al. 2011; Jo et al. 2009; Min et al. 2009). In addition, it is possible that growth of the trees themselves could be directly affected by the presence of AgNP as plants are known to be sensitive to nanoparticles (Yin et al. 2012). Therefore, this study aimed to determine the effect of AgNP contamination of soil on: (a) pine tree growth rates (shoot and root growth) and (b) ectomycorrhizal fungal colonisation of the pine tree roots.

\section{Experimental}

Soil preparation

Soil (the top $10 \mathrm{~cm}$ below the easily removed litter layer) was collected from a forested area of Point Reyes National Seashore (PRNS), California, USA, see (Branco et al. 2013) for site details. GPS location: N38 05.087 W122 52.253. After the removal of stones and larger material, the soil was air dried for $48 \mathrm{~h}$ prior to being sieved to $2 \mathrm{~mm}$ in the laboratory. Sterile sand (autoclaved for $30 \mathrm{~min}$ on three successive days) was added to the soil to $30 \% \mathrm{v} / \mathrm{v}$ to improve aeration during the experiment. AgNP (20 nm diameter, $99.8 \%$ purity, obtained from US Research Nanomaterials Inc, Texas 77084, USA) were added to a smaller portion of the soil $(\sim 100 \mathrm{~g})$ and mixed thoroughly (for 10 min using a metal spatula) to obtain a homogenous dispersion of AgNP. This $100 \mathrm{~g}$ of soil was then thoroughly mixed into larger soil volume in 'zip-loc' bags to obtain final AgNP levels of 350 and $790 \mathrm{mg} \mathrm{Ag} / \mathrm{kg}$ (see below). These AgNP levels were chosen as they were similar to those used in previous work (Kumar et al. 2011) and represent a high level of AgNP contamination. Non-contaminated control soil was also prepared in the same way but without the addition of AgNP. The soil:sand mix (65 ml volume) was then added to individual 'cone-tainers' (Steuwe and Sons, Corvallis, USA) and covered with a $1 \mathrm{~cm}$ depth of sterile sand. Altogether 14 replicates of each treatment $(0,350$ and $790 \mathrm{mg} \mathrm{Ag} / \mathrm{kg})$ were prepared.

\section{Soil analysis}

Dried soil $\left(40{ }^{\circ} \mathrm{C}\right)$ was analysed by the UC Davis College of Agricultural and Environmental Sciences Analytical Laboratory using standard methods (prior to experimental set-up). Soil texture $\mathrm{pH}$, organic $\mathrm{C}$,

Table 1 Soil properties

\begin{tabular}{lr}
\hline Total organic carbon $(\%)$ & 3.88 \\
Total N (\%) & 0.31 \\
Olsen-P $(\mathrm{mg} / \mathrm{kg})$ & 15.50 \\
pH & 4.94 \\
Sand $(\%)$ & 58.00 \\
Silt $(\%)$ & 18.00 \\
Clay $(\%)$ & 24.00 \\
\hline
\end{tabular}


Table 2 Ectomycorrhizal genera fund on roots from soils containing 0,350 and $790 \mathrm{mg} \mathrm{Ag} / \mathrm{kg}$

\begin{tabular}{lll}
\hline Control & $350 \mathrm{mg} \mathrm{AgNP} / \mathrm{kg}$ & $750 \mathrm{mg}$ AgNP/kg \\
\hline $\begin{array}{l}\text { Laccaria }(\times 3) \\
\text { Thelephora }\end{array}$ & Laccaria & None found \\
Rhizopogon occidentalis $(\times 2)$ & & \\
Tomentella $(\times 2)$ & & \\
Tuber & & \\
\hline
\end{tabular}

Table 3 Total and extractable Ag levels in contaminated soil samples

\begin{tabular}{ll}
\hline Total Ag in soil $(\mathrm{mg} / \mathrm{kg})$ & Extractable $\mathrm{Ag}$ in soil $(\mathrm{mg} / \mathrm{kg})$ \\
\hline Control & $<0.01$ (below detection limit) \\
350 & $12.07 \pm 0.85$ \\
790 & $15.44 \pm 1.19$ \\
\hline
\end{tabular}

total N, total P (Olsen), total silver and extractable silver were determined and results reported in Tables 1 , 2 and 3.

\section{Analysis of total silver in soil}

Soil samples were digested by nitric acid/hydrogen peroxide closed vessel microwave digestion and the total amount of silver in the digest analysed by ICPAES (UC Davis standard method 590.02).

\section{Extractable silver analysis of soil}

The level of extractable silver in triplicate samples obtained from each treatment at the end of the plant growth period (4 months: see below) was determined by the method of Hou et al. (2005). Briefly $1 \mathrm{~g}$ soil was added to $10 \mathrm{ml}$ of $1 \mathrm{M} \mathrm{NH}_{4} \mathrm{NO}_{3}(\mathrm{pH} 7)$ and shaken at $100 \mathrm{rpm}$ in an orbital shaker for $4 \mathrm{~h}$ at $25{ }^{\circ} \mathrm{C}$. The extract was collected by centrifugation at $3000 \mathrm{rpm} \times \mathrm{g}$ for $10 \mathrm{~min}$. Extracts were stored at $-20{ }^{\circ} \mathrm{C}$ until analysis by ICP-AES using standard methods at UC Davis.

Preparation and growth of Pinus muricata D. Don (Bishop pine) seedlings

Pinus muricata cones were collected from different trees in PRNS and dried in the laboratory to allow collection of seeds. Wings were removed from seeds and stored at $4{ }^{\circ} \mathrm{C}$ until required. To start germination, seeds were placed in $15 \%(\mathrm{v} / \mathrm{v}) \mathrm{H}_{2} \mathrm{O}_{2}$ solution plus tween 80 (one drop per $500 \mathrm{ml}$ ) and stirred for $15 \mathrm{~min}$. Seeds were then collected in a sieve, rinsed with deionised water and finally soaked in deionised water for $24 \mathrm{~h}$ prior to planting in soil. Three seeds were planted in each cone-tainer (prepared as described above) and distilled water added until saturated soil moisture conditions were achieved (maintained throughout the experiment). Cone-tainers were incubated at $20{ }^{\circ} \mathrm{C}$ in a growth chamber set at a constant light intensity of $\sim 220 \mu \mathrm{mol} \mathrm{m} \mathrm{m}^{-2}$.

Sampling of plants and soil

Seedlings were thinned to one per cone-tainer after a period of 1 month, and the thinned seedlings used for initial experimental observations of root length, root and shoot fresh weight. The remaining seedlings were grown for a further 4 months and destructively harvested for measurement of shoot and root fresh weight and ectomycorrhizal diversity on roots. Soil was also analysed for extractable silver levels after 4 months (see above).

Collection of ectomycorrhizal roots, DNA extraction and PCR

Root tips were collected from a random subsample (from five cone-tainers) of the different AgNP-treated pine seedlings. The aim of the experiment was to observe the total diversity of ECM present. So roots that displayed different ectomycorrhizal root morphology (such as variations in colour, diameter and tissue density (Comas et al. 2014) were preferentially collected. Most of the AgNP-treated plants showed no obvious visual ECM colonisation so 'normal' roots were collected in an attempt to discover if any ectomycorrhizal colonisation was present. Overall, a total of 10 root tip samples were collected from each 
treatment and were subjected to immediate extraction using the REDExtract-N-Amp Tissue PCR Kit (Sigma-Aldrich, Saint Louis, MO, USA). Each root tip was added to $20 \mu \mathrm{L}$ of extraction buffer and incubated at $95{ }^{\circ} \mathrm{C}$ for $10 \mathrm{~min}$. Then $20 \mu \mathrm{L}$ neutralisation buffer was immediately added and the extracts stored at $-20{ }^{\circ} \mathrm{C}$ prior to PCR. PCR was carried under using standard conditions with the fungal specific primer pair ITS1f and ITS4 (Gardes and Bruns 1993; White et al. 1990). PCR products were cleaned using AmPURE magnetic beads following manufacturers recommendations. PCR products were sequenced in forward and reverse directions using an ABI3170 Genetic Analyser (Applied Biosystems, Foster City, CA, USA). Fungi were defined using a $97 \%$ sequence similarity cut-off and named according to the nearest BLAST match.

\section{Statistical analysis}

All data were analysed by one-way ANOVA and differences between individual means were determined by post hoc least significance difference analysis using SPSS version 21.

\section{Results}

No effect of AgNP contamination was observed on seedling germination and emergence (results not shown) and subsequently tree growth was analysed after 1 and 4 months. After 1 month, shoot fresh weight in the highest $\mathrm{Ag}$ level was slightly but significantly $(p<0.05)$ reduced by approximately $15 \%$ (Fig. 1A) compared to the non-contaminated control, while shoot fresh weight at the lower AgNP level was not significantly affected. The primary tap root produced by pine in the presence of higher AgNP levels was significantly shorter $(p<0.05)$ than the primary roots produced in control and lower AgNP levels (Fig. 1B, supplementary Fig. 1) but had the same fresh weight value (data not shown) despite being shorter (supplementary Fig. 1). This appeared to be related to root thickness being increased at the higher AgNP level. After 4 months, both root and shoot growth were highly reduced in soils containing AgNP. For example, at $350 \mathrm{mg} \mathrm{Ag} / \mathrm{kg}$, shoot and root fresh weight was reduced by approximately 72 and $57 \%$, respectively (Fig. 1C, D).
Molecular-based identification of ECM

PCR products were obtained for all the control root tip DNA extracts (10/10) and nine of these gave successful DNA sequences. In contrast, only three out of the ten samples with $350 \mathrm{mg} \mathrm{Ag} / \mathrm{kg}$ revealed positive PCR products and only one produced a successful DNA sequence. For the final set of samples ( $790 \mathrm{mg} \mathrm{Ag} / \mathrm{kg}$ ), no PCR products were obtained for any of the root tip DNA extracts. Despite this, a random selection $(n=3)$ of these samples were still sequenced in case extremely low levels of PCR product were produced. Yet, no sequences were obtained for any of these samples.

Five ectomycorrhizal genera were found on roots of the control plants. Only one genus Laccaria was found on roots of pine grown in soil contaminated with $350 \mathrm{mg} \mathrm{Ag} / \mathrm{kg}$, and this was found on roots growing at the interface between the contaminated soil and sterile sand used to cover the soil surface. No ectomycorrhiza were found on roots in soil containing the highest AgNP level. Finally, we measured the levels of extractable silver in the soil samples. After 4 months, levels of extractable silver were determined to be approximately $3 \%$ of the total silver present in the soil at $350 \mathrm{mg} \mathrm{Ag} / \mathrm{kg}$ soil (Table 3). Extractable silver levels were found to increase in the soil containing more silver; howeve, r this was not significant.

\section{Discussion}

The predicted increase in nanoparticle levels in sewage sludge and the applications of resulting biosolids to land (Judy et al. 2011) means that the effect of nanoparticle contamination on plant:microbial interactions requires further study. This work focussed on the effect of AgNP on establishment of ectomycorrhiza on Bishop pine. As far as we are aware, this is the first study of the effects of AgNP on pine growth and their ectomycorrhizal associations.

AgNP have varying effects on plants depending on the plant species, growth conditions (e.g. growth in soil or different nutrient media) and the level and type of AgNP applied (e.g. surface modified or untreated) making result comparisons difficult. However, most studies have shown that AgNP exposure of plants has a deleterious effect on growth. In this study, we show that pine seedling germination was not reduced by 

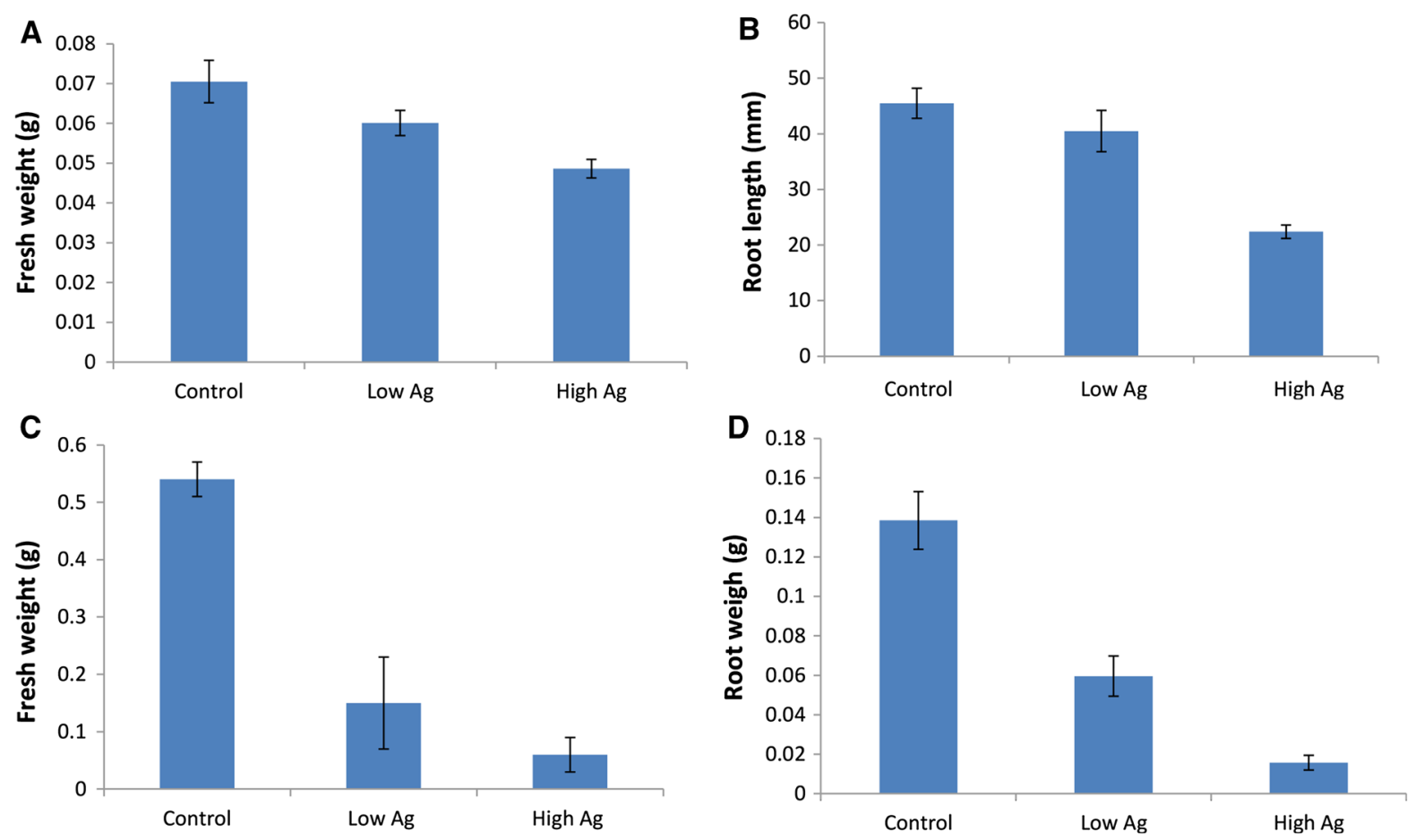

Fig. 1 A Illustrates Bishop pine shoot fresh weight after one month of growth in soil containing different levels of AgNP. B The effect of AgNP soil contamination on Bishop pine root length after 1 month of growth. C The reduction in shoot fresh

AgNP exposure while in contrast previous work has shown a variety of effects ranging from stimulation to a reduction in germination (Yin et al. 2012).

Here we show that root development in AgNPexposed Bishop pine grown in soil was severely affected. Lateral root development was observed in controls (no AgNP) but lateral root formation in test treatments was reduced. In the highest AgNP level, only one vertical root was generally formed and only a few lateral roots were found in plants grown at the lower AgNP level (350 mg AgNP/kg), a result likely due to the roots being restricted to the soil surface layer (between the AgNP-contaminated soil and sterile sand added to the soil surface). Supporting these results, significant effects of AgNP on plant roots have been observed in previous studies on Phaseolus radiatus and Sorghum bicolor (Lee et al. 2012) and on wetland plants (Yin et al. 2012). Specifically, it has been suggested that AgNP exposure affects fundamental root growth processes such as gravitropism (Yin et al. 2011). It may be expected that the reduction in plant root growth caused by AgNP may lead to a

weight caused by AgNP soil contamination after 4 months growth and $\mathbf{D}$ reduction in root fresh weight caused by AgNP after 4 months growth. Control related to $0 \mathrm{mg} \mathrm{Ag} / \mathrm{kg}$, low levels relate to $350 \mathrm{mg} \mathrm{Ag} / \mathrm{kg}$ and high related to $790 \mathrm{mg} \mathrm{Ag} / \mathrm{kg}$

reduction in above ground biomass, due to decreased nutrient uptake. This study showed exactly that, with contaminated soils showing lower levels of biomass. However, it may be possible that this reduced growth may be due to $\mathrm{Ag}+$ or AgNP being taken up by the plant and translocated to the shoots, resulting in direct above ground toxicity effects. Indeed, plant uptake of gold nanoparticles has been observed in tobacco to the same effect (Judy et al. 2011).

The marked effect of AgNP exposure on plant roots (in particular less lateral roots formed) is the most likely explanation for the reduction in ectomycorrhizal diversity observed in this work. Ectomycorrhizal associations on roots from control soils were clearly visible and a variety of types were observed. However, no obvious ectomycorrhizal roots were seen in any of the AgNP-contaminated soils, and the few root tip samples available in silver exposed soils were taken in case any ectomycorrhizal root associations had formed but were not observable. The ectomycorrhizal species found in control soils were typical of those found previously in Point Reyes soils (Peay et al. 2010) and 
BLAST searches came up with matches most similar to ectomycorrhiza previously found in Point Reyes soil samples. The development of an ectomycorrhizal association with a plant root is a complex process with the precolonisation stage involving interactions between the plant host and the fungus (Ditengou et al. 2000; Felten et al. 2009; Martin et al. 2001) and mycorrhiza helper bacteria (MHB) (Bending 2007; Cusano et al. 2011). It is possible that AgNP exposure of plant roots, the fungal partner and MHB could affect such interactions thereby reducing the potential for mycorrhizal formation. Following root colonisation, it has been demonstrated that both fungal and plant gene and protein production alters in response to infection (Heller et al. 2008; Tarkka et al. 2001). Therefore, even if a fungus was able to initiate infection then the silver contamination may alter gene expression in both partners resulting in a reduction in speed or extent of colonisation.

Previous work examining the toxicity of silver and AgNP towards fungi has shown that AgNP levels below $10 \mathrm{ppm}$ in agar can reduce fungal colony formation from conidia (Jo et al. 2009). Interestingly, the soil extraction technique used in this study indicated that a significant proportion of silver was available (12 mg Ag/L soil solution) and could therefore affect fungal growth assuming that the $\mathrm{Ag}$ present was in a form bioavailable to fungi. The toxic effect of silver on fungal conidial germination and growth would serve to reduce ectomycorrhizal root formation as fungal colonisation of roots from new seedlings would mainly be established via fungal spores from the existing soil spore bank or hyphal growth from an established symbiosis.

It is thought that the toxicity of AgNP is related to release of soluble $\mathrm{Ag}+$ from the particle (Sweet and Singleton 2011) although there is evidence indicating that AgNP themselves can be taken up by cells (not observed yet with fungi) and release $\mathrm{Ag}+$ intracellularly (Park et al. 2010). Fungal interaction with insoluble particles has been demonstrated previously (Singleton et al. 1990), so it is possible that AgNP could attach to fungal cell surfaces (spores and/or hyphae) and thereby deliver a concentrated pulse of $\mathrm{Ag}+$ causing cell wall damage, preventing spore germination and/or reducing hyphal growth.

The extractability and toxicity of AgNP in soil is known to be dependent on a variety of soil factors (Calder et al. 2012; Coutris et al. 2012) and the availability of $\mathrm{Ag}$ from $\mathrm{AgNP}$ has recently been shown to increase with time using sequential extraction techniques (Coutris et al. 2012). Interestingly, both humic acids and microbes have been shown to cause AgNP formation from Ag+ (Akaighe et al. 2011; Sweet and Singleton 2011) which would theoretically reduce $\mathrm{Ag}$ bioavailability. Together, this presents a complex picture of AgNP behaviour in soil meaning that different soils will demonstrate different levels of $\mathrm{Ag}$ bioavailability and toxicity. It is also likely that plants and fungi will demonstrate differential access to the bioavailable fraction of $\mathrm{Ag}$ due to their varying abilities to take up $\mathrm{Ag}$ when complexed with soil derived compounds.

\section{Conclusions}

Overall, AgNP contamination of soil resulted in a marked effect on Bishop pine root and shoot biomass and a reduction in ectomycorrhizal fungal species found in symbiosis with plant roots. It is likely that a combination of $\mathrm{Ag}$ derived toxicity effects on plant roots and fungal symbionts reduced the diversity of ectomycorrhizal fungi found. The levels of AgNP used in this work were relatively high, and it is recommended that future work be carried out with a range of AgNP levels. We propose that lower levels of AgNP could still affect ectomycorrhizal symbiosis due to the subtle interactions occurring between the plant host, fungal symbiont, and MHB on a gene expression level. Due to the complex behaviour of AgNP in soils, it is likely that the AgNP effects observed here will vary widely in soils of different characteristics and a range of soils should be examined. Finally, any future research must take into account the type of AgNP used (unmodified AgNPs were used in this work) as chemical modification of NP is common and such changes to AgNP are known to affect their behaviour in soil (Coutris et al. 2012).

Acknowledgments This work was supported by the award of an EC FP7 Marie Curie International Outgoing Fellowship to IS. The authors would like to thank Sydney Glassman for providing Bishop pine seeds, Toms Bruns for useful discussions, Sara Branco for help with examining plant roots and DNA extraction protocols and Nhu Nguyen for advice on growing Bishop pine. The Mycorrhiza Reading Group, Department of Plant and Microbial Biology, UC Berkeley is also thanked for comments and helpful advice. 
Open Access This article is distributed under the terms of the Creative Commons Attribution 4.0 International License (http:// creativecommons.org/licenses/by/4.0/), which permits unrestricted use, distribution, and reproduction in any medium, provided you give appropriate credit to the original author(s) and the source, provide a link to the Creative Commons license, and indicate if changes were made.

\section{References}

Akaighe N, MacCuspie RI, Navarro DA, Aga DS, Banerjee S, Sohn M, Sharma VK (2011) Humic acid-induced silver nanoparticle formation under environmentally relevant conditions. Environ Sci Technol 45:3895-3901. doi:10. 1021/es103946g

Bending GD (2007) What are the mechanisms and specificity of mycorrhization helper bacteria. New Phytol 174:707-710. doi:10.1111/j.1469-8137.2007.02076.x

Benn TM, Westerhoff P (2008) Nanoparticle silver released into water from commercially available sock fabrics. Environ Sci Technol 42:4133-4139. doi:10.1021/es7032718

Benn T, Cavanagh B, Hristovski K, Posner JD, Westerhoff P (2010) The release of nanosilver from consumer products used in the home. J Environ Qual 39:1875-1882. doi:10. 2134/jeq2009.0363

Branco S, Bruns TD, Singleton I (2013) Fungi at a small scale: spatial zonation of fungal assemblages around single trees. PLoS ONE. doi:10.1371/journal.pone.0078295

Calder AJ, Dimkpa CO, McLean JE, Britt DW, Johnson W, Anderson AJ (2012) Soil components mitigate the antimicrobial effects of silver nanoparticles towards a beneficial soil bacterium, Pseudomonas chlororaphis O6. Sci Total Environ 429:215-222. doi:10.1016/j.scitotenv. 2012.04.049

Comas LH, Callahan HS, Midford PE (2014) Patterns in root traits of woody species hosting arbuscular and ectomycorrhizas: implications for the evolution of belowground strategies. Ecol Evol 4(15):2979-2990

Coutris C, Joner EJ, Oughton DH (2012) Aging and soil organic matter content affect the fate of silver nanoparticles in soil. Sci Total Environ 420:327-333. doi:10.1016/j.scitotenv. 2012.01.027

Cusano AM, Burlinson P, Deveau A, Vion P, Uroz S, Preston GM, Frey-Klett P (2011) Pseudomonas fluorescens BBc6R8 type III secretion mutants no longer promote ectomycorrhizal symbiosis. Environ Microbiol Rep 3(2):203-210. doi:10.1111/j.1758-2229.2010.00209.x

Ditengou FA, Beguiristain T, Lapeyrie F (2000) Root hair elongation is inhibited by hypaphorine, the indole alkaloid from the ectomycorrhizal fungus Pisolithus tinctorius, and restored by indole-3-acetic acid. Planta 211:722-728. doi: $10.1007 / \mathrm{s} 004250000342$

Farkas J et al (2011) Characterization of the effluent from a nanosilver producing washing machine. Environ Int 37:1057-1062. doi:10.1016/j.envint.2011.03.006

Felten J et al (2009) The ectomycorrhizal fungus Laccaria bicolor stimulates lateral root formation in poplar and arabidopsis through auxin transport and signaling. Plant Physiol 151:1991-2005. doi:10.1104/pp.109.147231

Finlay RD (2008) Ecological aspects of mycorrhizal symbiosis: with special emphasis on the functional diversity of interactions involving the extraradical mycelium. J Exp Bot 59:1115-1126. doi:10.1093/jxb/ern059

Gardes M, Bruns TD (1993) ITS primers with enhanced specificity for basidiomycetes-application to the identification of mycorrhiza and rusts. Mol Ecol 2:113-118

George C, Kuriakose S, George S, Mathew T (2011) Antifungal activity of silver nanoparticle-encapsulated beta-cyclodextrin against human opportunistic pathogens. Supramol Chem 23:593-597. doi:10.1080/10610278.2011. 575471

Gordon GJ, Gehring CA (2011) Molecular characterization of pezizalean ectomycorrhizas associated with Pinyon pine during drought. Mycorrhiza 21:431-441. doi:10.1007/ s00572-010-0349-8

Heller G et al (2008) Transcriptional analysis of Pinus sylvestris roots challenged with the ectomycorrhizal fungus Laccaria bicolor. BMC Plant Biol. doi:10.1186/1471-2229-8-19

Hou A, Takamatsu T, Koshikawa MK, Hosomi M (2005) Migration of silver, indium, tin, antimony, and bismuth and variations in their chemical fractions on addition to uncontaminated soils. Soil Sci 170:624-639. doi:10.1097/ 01.ss.0000178205.35923.66

Jo YK, Kim BH, Jung G (2009) Antifungal activity of silver ions and nanoparticles on phytopathogenic fungi. Plant Dis 93:1037-1043. doi:10.1094/pdis-93-10-1037

Judy JD, Unrine JM, Bertsch PM (2011) Evidence for biomagnification of gold nanoparticles within a terrestrial food chain. Environ Sci Technol 45:776-781. doi:10.1021/ es103031a

Kumar N, Shah V, Walker VK (2011) Perturbation of an arctic soil microbial community by metal nanoparticles. J Hazard Mater 190:816-822. doi:10.1016/j.jhazmat.2011.04.005

Lee W-M, Kwak JI, An Y-J (2012) Effect of silver nanoparticles in crop plants Phaseolus radiatus and Sorghum bicolor: media effect on phytotoxicity. Chemosphere 86:491-499. doi:10.1016/j.chemosphere.2011.10.013

Marambio-Jones C, Hoek EMV (2010) A review of the antibacterial effects of silver nanomaterials and potential implications for human health and the environment. J Nanopart Res 12:1531-1551. doi:10.1007/s11051-0109900-y

Martin F, Duplessis S, Ditengou F, Lagrange H, Voiblet C, Lapeyrie F (2001) Developmental cross talking in the ectomycorrhizal symbiosis: signals and communication genes. New Phytol 151:145-154. doi:10.1046/j.14698137.2001.00169.x

Mathew TV, Kuriakose S (2013) Studies on the antimicrobial properties of colloidal silver nanoparticles stabilized by bovine serum albumin colloids and surfaces B. Biointerfaces 101:14-18. doi:10.1016/j.colsurfb.2012.05.017

Min JS et al (2009) Effects of colloidal silver nanoparticles on sclerotium-forming phytopathogenic fungi. Plant Pathol J 25:376-380. doi:10.5423/ppj.2009.25.4.376

Park E-J, Yi J, Kim Y, Choi K, Park K (2010) Silver nanoparticles induce cytotoxicity by a Trojan-horse type mechanism. Toxicol In Vitro 24:872-878. doi:10.1016/j.tiv.2009. 12.001 
Peay KG, Garbelotto M, Bruns TD (2010) Evidence of dispersal limitation in soil microorganisms: isolation reduces species richness on mycorrhizal tree islands. Ecology 91:36313640. doi:10.1890/09-2237.1

Singleton I, Wainwright M, Edyvean RGJ (1990) Novel biorecovery methods for industrial waste-water treatment. Biorecovery 1(4):271-289

Sousa NR, Franco AR, Oliveira RS, Castro PML (2012) Ectomycorrhizal fungi as an alternative to the use of chemical fertilisers in nursery production of Pinus pinaster. J Environ Manage 95:S269-S274. doi:10.1016/j.jenvman.2010. 07.016

Sweet MJ, Singleton I ((2011) Silver nanoparticles: a microbial perspective. Adv Appl Microbiol 77:116-127. doi:10. 1016/b978-0-12-387044-5.00005-4

Tarkka MT, Nyman TA, Kalkkinen N, Raudaskoski M (2001) Scots pine expresses short-root-specific peroxidases during development. Eur J Biochem 268:86-92. doi:10.1046/j. 1432-1327.2001.01853.x

Valdecantos A, Cortina J, Vallejo VR (2011) Differential field response of two Mediterranean tree species to inputs of sewage sludge at the seedling stage. Ecol Eng 37:1350-1359. doi:10.1016/j.ecoleng.2011.03.017

White TJBT, Lee S, Taylor J (1990) Amplification and direct sequencing of fungal ribosomal RNA genes for phylogenetics. In: InnisDH MA, Gefland JJ, Sninsky TJ (eds) White PCR protocols: a guide to methods and applications. Academic Press, San Diego, pp 315-322

Yin L et al (2011) More than the ions: the effects of silver nanoparticles on Lolium multiflorum. Environ Sci Technol 45:2360-2367. doi:10.1021/es103995x

Yin L, Colman BP, McGill BM, Wright JP, Bernhardt ES (2012) Effects of silver nanoparticle exposure on germination and early growth of eleven wetland plants. PLoS ONE. doi:10. 1371/journal.pone.0047674

Zhang Z, Kong F, Vardhanabhuti B, Mustapha A, Lin M (2012) Detection of engineered silver nanoparticle contamination in pears. J Agric Food Chem 60:10762-10767. doi:10. 1021/jf303423q 